\title{
Immunohistochemistry, histopathology and ultrastructure of Gasterosteus aculeatus tissues infected with Glugea anomala
}

\author{
B. S. Dezfuli ${ }^{1, *}$, L. Giari ${ }^{1}$, E. Simoni ${ }^{1}$, A. P. Shinn ${ }^{2}$, G. Bosi ${ }^{3}$ \\ ${ }^{1}$ Department of Biology, University of Ferrara, Via Borsari, 46, 44100 Ferrara, Italy \\ ${ }^{2}$ Institute of Aquaculture, University of Stirling, Stirling FK9 4LA, UK \\ ${ }^{3}$ Department of Veterinary Sciences and Technologies for Food Safety, University of Milan, Via Trentacoste, 2, 20134 Milan, Italy
}

\begin{abstract}
Immunohistochemical and histopathological studies were conducted on a population of 3-spined sticklebacks Gasterosteus aculeatus (L.) from Loch Airthrey (Stirling, Scotland) naturally infected with the microsporean Glugea anomala (Moniez 1887). Of the 55 host specimens that were examined, $16(29.09 \%)$ were infected, the intensity of infection ranging from 1 to 4 xenomas per fish, which were principally located within the central portion of the body lateral flank musculature. All 32 G. anomala xenomas examined were mature, their diameter ranging from 936 to $2232 \mu \mathrm{m}$, and their walls of presented a laminar structure. Subcutaneously situated xenomas protruded from the fish body surface, whilst xenomas encountered within the intestine were seen to cause distortion. Light and electron microscopical observations confirmed a host cellular reaction around the xenoma, seen by the presence of eosinophile granule cells (EGCs), and some neutrophils. The occurrences of rodlet cells among the intestinal epithelial cells, and in close proximity to the xenoma wall, were observed in certain specimens. Outside the xenoma wall, macrophage aggregates (MAs) were commonly encountered. Within the xenoma wall, the presence of eosinophile granular cells immunoreactive to the anti-serotonin serum was also recorded. Further immunohistochemical tests revealed that a high number of nerve fibres running along the white lateral muscle fibres were immunoreactive to bombesin-, galanin-, and leu-enkephalin-antisera. Nerve fibres containing bombesin- and leu-enkephalin-like substances were also observed in the connective inflammatory tissue around the protozoan cyst, while neurons in the spinal ganglia were immunoreactive to met-enkephalin, and serotonin antisera. The control for the specificity of immunohistochemical reactions was performed using preabsorption tests of each antiserum with the corresponding antigen, and no immunoreactivity was noticed. The data presented are discussed in relation to the occurrence of G. anomala, which alters the pattern of nerve fibres present in the host. Specifically, the protozoan induces a response in the stickleback nervous system, the reaction of which is revealed through the application of immunohistochemical techniques.
\end{abstract}

KEY WORDS: Glugea anomala infection · Immunohistochemistry · Ultrastructure • Cellular responses · Gasterosteus aculeatus

\section{INTRODUCTION}

Thélohan erected the genus Glugea in 1891 after the species G. anomala (Moniez 1887) was discovered for the first time as a parasite of 3-spined sticklebacks Gasterosteus aculeatus (L.) (see Sprague \& Vernick
1968). Of the available records on Glugea within the literature, most accounts focus on the taxonomy of the Microsporidia (Lom et al. 1995, Lom \& Pekkarinen 1999, Larsson 2000, Pomport-Castillon et al. 2000). From earlier accounts, the nature and origin of the cytoplasmic layer and the nuclei of Glugea xenomas 
were debated until Weissenberg (1922) proposed the now-accepted theory that the cytoplasmic layer and large nuclei originate from a hypertrophied host cell.

Of the papers focusing specifically on Glugea anomala, there is only 1 account which deals with the host tissue reaction: Dykovà \& Lom (1978) reported the occurrence of an inflammatory process despite the fact that this protozoan is intracellular. There are, however, a few reports in the literature on a species of Glugea, G. hertwigi (Weissenberg), which has caused mortalities in populations of rainbow smelt Osmerus mordax (Mitchill 1814) (see Delisle 1972, Nepszy et al. 1978).

During the present survey of infected fish, macrophage aggregates (MAs) were encountered in bodywall tissue surrounding Glugea anomala xenomas. This study will attempt to establish the relationship between the presence of MAs and G. anomala. In addition to the existence of MAs in Glugea-infected fish, our study also noted the occurrence of rodlet cells (RCs) within the intestinal epithelium overlying the xenoma wall.

While the presence and physiological features of fish neuropeptides have been well documented (Karila et al. 1998, Shahbazi et al. 1998, Domeneghini et al. 2000), those in infected fish have received less attention. Of the surveys that have been undertaken in infected fish, Maule et al. (1989) studied a pancreatic polypeptide in Merlangius merlangus (Nordmann) parasitized with the monogenean Diclidophora merlangi (Nordmann, 1832), and Dezfuli et al. (2000b, 2002, 2003b) conducted a series of detailed investigations on the neuropeptides of Salmo trutta (L.) infected with a range of helminths. Interestingly, one study found that the nerve fibres in the myenteric plexus and in the connective capsule surrounding the praesoma of the acanthocephalan Pomphorhynchus laevis (Müller) were positive to several neuroedocrine sera (Dezfuli et al. 2002). This study noted that there were some similarities between the capsule surrounding the acanthocephalan parasitising brown trout (Salmo trutta L.) and that which formed around the Glugea xenoma. With this in mind, and given the lack of information on the immunohistochemical reactions in fish parasitized by Glugea spp., this study will assess the activity of a variety of neuropeptides in infected and non-infected hosts. The results from this investigation will be discussed alongside the observations made on the histopathology and ultrastructure of the cells involved in the host reaction.
Table 1. Primary antisera tested on tissue sections of Gasterosteus aculeatus infected with Glugea anomala

\begin{tabular}{|c|c|c|c|}
\hline bit & Source & Code & Working dilution \\
\hline \multirow{9}{*}{ ed peptide } & Biogenesis & $1400-0004$ & $1: 200$ \\
\hline & Peninsula $^{a}$ & IHC 6006 & $1: 500$ \\
\hline & Chemicon & AB 1985 & $1: 250$ \\
\hline & Genosys $^{b}$ & CA-08-235 & $1: 1000$ \\
\hline & Chemicon & AB 1975 & $1: 1000$ \\
\hline & Biogenesis & $6730-0004$ & $1: 50$ \\
\hline & Chemicon & 61066 & $1: 100$ \\
\hline & Peninsula & IHC 8001 & $1: 250$ \\
\hline & Chemicon & AB 1977 & $1: 250$ \\
\hline tide & Genosys & CA-08-340 & $1: 500$ \\
\hline
\end{tabular}

\section{MATERIALS AND METHODS}

During September 2002, 55 specimens of Gasterosteus aculeatus (ranging from 22 to $47 \mathrm{~mm}$ in total length) were collected from Loch Airthrey, a small waterbody (area 6.9 ha, mean depth $1.85 \mathrm{~m}$ ) situated on the campus of Stirling University. After sampling, the fish were maintained in an aquarium until they could be processed. Fish were anesthetized using MS222 (Sandoz) and then the spinal cord was severed. At post-mortem, the position of both the externally visible and internally situated Glugea xenomas found on dissection were recorded. Pieces of fish tissue, measuring up to $15 \times 15 \mathrm{~mm}$ in size, with the xenomas in situ, were excised and fixed in chilled $\left(4^{\circ} \mathrm{C}\right)$ Bouin's fluid for $7 \mathrm{~h}$. The samples were then transferred to $80 \%$ alcohol and dehydrated through an alcohol series and prepared for paraffin embedding. Cut sections $(7 \mu \mathrm{m}$ thick) were stained with either haematoxylin-eosin, Azan-Mallory or periodic acid Schiff (PAS) stain, or used for immunohistochemical analysis. G. aculeatusG. anomala xenoma tissue sections were processed using the indirect immunohistochemical method (peroxidase-anti-peroxidase immunocomplex) as outlined in Dezfuli et al. (2002, 2003b). The antisera used are reported in Table 1 . The controls for the specificity of the immunohistochemical reactions were performed by the preabsorption of each antiserum with the corresponding antigen (Table 2). Mammalian (pig, rat) tissue sections were used as a positive control.

Table 2. Peptides used for absorption controls. All aptenes are from Sigma Chemicals, St. Louis, MO (USA)

\begin{tabular}{|lc|}
\hline Peptide & Code \\
\hline Bombesin & B4272 \\
Galanin & G-112 \\
Leu-eukephalin & L9133 \\
Met-enkephalin & E5757 \\
Serotonin & H9523 \\
\hline
\end{tabular}


For the light and electron microscopy study, host tissues measuring up to $7 \times 7 \mathrm{~mm}$ in diameter were fixed for $2 \mathrm{~h}$ in chilled $\left(4^{\circ} \mathrm{C}\right) 2 \%$ glutaraldehyde solution buffered at $\mathrm{pH} 7.2$ with $0.1 \mathrm{M}$ sodium cacodylate. After $2 \mathrm{~h}$ in glutaraldehyde at $4^{\circ} \mathrm{C}$, the pieces were rinsed for $12 \mathrm{~h}$ in $0.1 \mathrm{M}$ sodium cacodylate buffer containing $5 \%$ sucrose. The specimens were then postfixed in $1 \%$ osmium tetroxide in the same buffer for $2 \mathrm{~h}$, dehydrated in graded ethanol, transferred to propylene oxide and embedded in an Epoxy-Araldite ${ }^{\circledR}$ mixture. Semi-thin sections $(5 \mu \mathrm{m})$ were cut on a Reichert Om U 2 ultramicrotome and stained with azure-A methylene blue. Ultrathin sections (90 nm) were stained with a solution of $4 \%$ uranyl acetate in $50 \%$ alcohol and Reynold's lead citrate, and examined using a Zeiss EM9 transmission microscope. For comparative purposes, the tissues of 10 uninfected Gasterosteus aculeatus were processed alongside the parasitised material.

\section{RESULTS}

Sixteen out of 55 (29.09\%) Gasterosteus aculeatus were parasitized with xenomas of Glugea anomala. The intensity of infection ranged from 1 to 4 xenomas per fish (mean \pm SE: $2.12 \pm 0.26$ xenomas per parasitised fish). Most xenomas (size range of 936 to $2232 \mu \mathrm{m}$, mean \pm SE: $1676.24 \pm 126.56$ ) were situated within the body wall musculature. Subcutaneous, mature xenomas protruded from the host body surface, both internally (Fig. 1) and externally. Given the proportionately large size of mature xenomas, the displacement, and occasional compression of the internal organs and intestines in certain individuals was observed (Fig. 2). Of the G. aculeatus maintained in the aquarium, 1 or 2 individuals had visible xenomas situated within the opercular cavity. These fish typically swam near the water's surface and exhibited an increased respiration rate. The gill histopathology of 1 such individual can be clearly seen in Fig. 2. Here, the xenoma occupies most of the available space within the opercular cavity, and the gill lamellae have all but disappeared.

In 3 out of 16 infected fish, xenomas were encountered on the external surface of the hind-gut (Fig. 3). In these samples, rodlet cells were present among the epithelial cells of the intestine that were in close proximity to the xenoma wall. The wall of these xenomas frequently made direct contact with the host's internal organs and cells (Figs. $3 \& 4$ respectively).

Fig. 5 shows a higher magnification of the periphery of the xenoma (cyst). Moving from the centre of the xenoma towards the cyst wall, there are numerous sporophorous vesicles with mature spores within, then a layer of mature spores, then a region displaying increased pinocytotic activity, and finally the xenoma wall which is composed of a laminar layer (Figs. 4 \& 5). Among the host cells that surround the xenoma, there are large dilated structures that appear as vesicles filled with an amorphous, lucent material (Fig. 4).

Fig. 6 clearly documents the occurrence of additional host cell types around the xenoma, such as fibroblasts, which line the outer part of the xenoma wall. Capillaries were also evident between the host cells, and within these vessels some degree of endothelial activation, as seen as endothelial cell plasmalemma projections which enhance their stickiness and adhesion to leucocytes, was evident. Neutrophils were also seen within the tissue but notably around the capillaries. Eosinophile granule cells (EGCs) were also present, as shown in Fig. 7, but no evidence of degranulation of these cells was encountered. Macrophage aggregates (MAs) were found around the outer part of xenoma wall (Fig. 8) and several EGCs containing a serotonin (5-HT)-like material were observed in the connective tissue around the protozoan cyst (Fig. 9). Immunohistochemical testing of Gasterosteus aculeatus tissue sections infected with Glugea anomala, using 10 neuromodulators, gave positive results for bombesin, galanin, leu- and met-enkephalin and serotonin antisera. In particular, some neurons of the spinal ganglia were immunoreactive to the 5-HT (Fig. 10) and metenkephalin antisera (Fig. 11). A high number of nerve fibres running along the white muscle fibres in the lateral muscles and in close proximity to the $G$. anomala cyst had a positive reaction to anti-galanin, antileu-enkephalin, and anti-bombesin sera (Figs. 12 \& 13). Nerve fibres within the connective elements of the G. anomala cyst were also immunoreactive to the antibodies against leu-enkephalin and bombesin (Figs. 14 \& 15). Immunohistochemical staining of histological sections through $G$. aculeatus body-wall xenoma tissue with the antibodies anti-neuropeptide $Y$, anti-somatostatin, -substance $\mathrm{P}$, and -vasoactive intestinal peptide, however, did not reveal any positive structures. Furthermore, no immunoreactivity was observed on the sections treated with preabsorbed antisera, and the mammalian (pig, rat) tissue sections, which were used as positive controls, gave their expected immunoreactivities.

\section{DISCUSSION}

Weissenberg (1968) first applied the term 'xenoma' to the cysts of Glugea anomala, adopting the term to distinguish the microsporidean cysts of genus Glugea from those of Perezia Léger \& Duboscq, 1909. Indeed, much of our present-day knowledge on the morphol- 

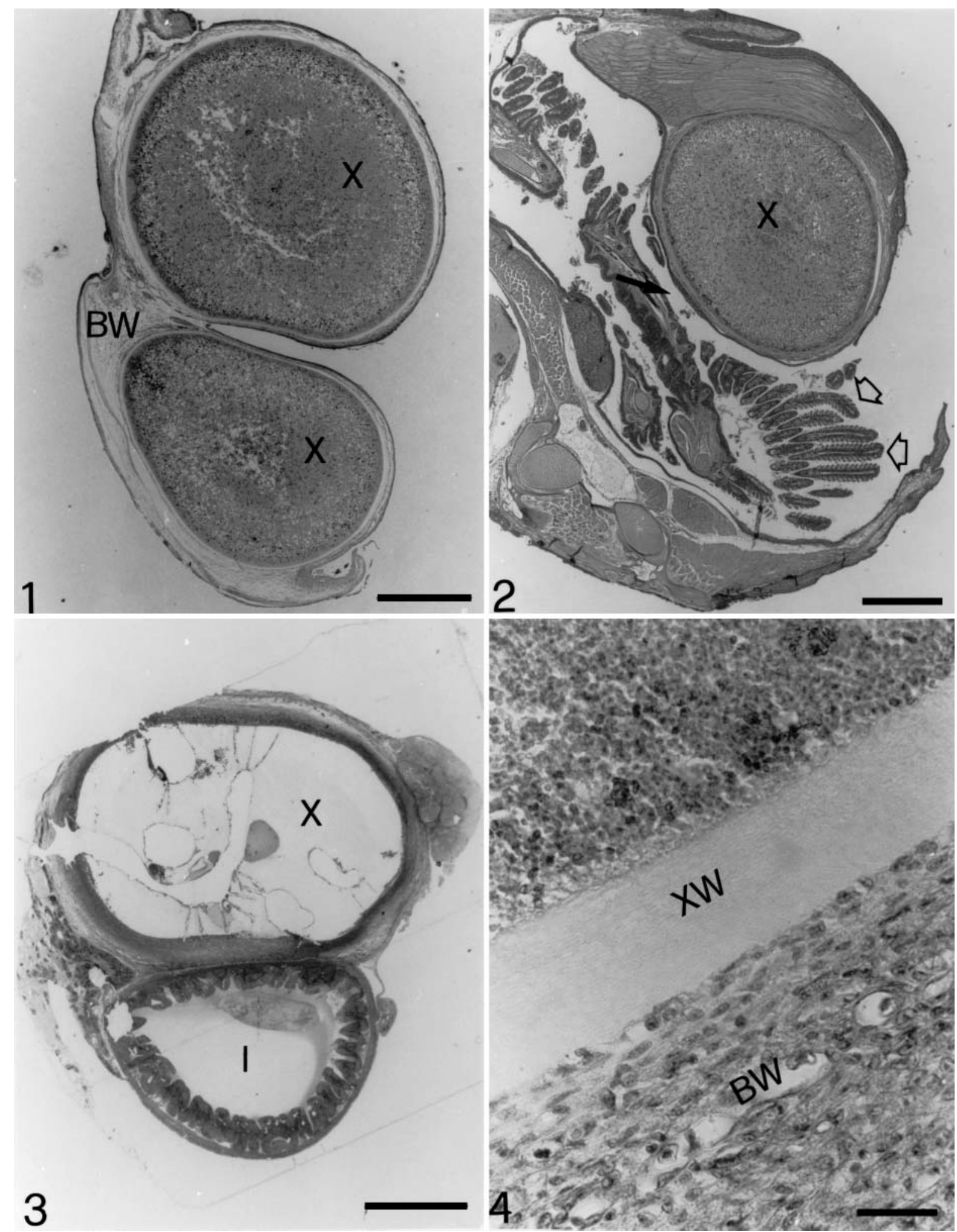

Figs. 1 to 4. Gasterosteus aculeatus infected by Glugea anomala; histological sections. Fig. 1. Sections of body wall (BW) of G. aculeatus infected with 2 xenomas of $G$. anomala (X). Scale bar $=600 \mu \mathrm{m}$. Fig. 2. Compression of the gill lamellae (arrows) as a result of xenoma growth can be clearly seen. Open arrows identify gill lamellae. Scale bar $=500 \mu \mathrm{m}$. Fig. 3 . Contact between the xenoma and the host's intestine (I). Scale bar $=500 \mu \mathrm{m}$. Fig. 4. High magnification of the interfacing region between the xenoma wall $(X W)$ and the host body wall; arrows show vesicles filled with amorphous, lucent material. Scale bar $=20 \mu \mathrm{m}$ 
ogy and development of Glugea is a result of the investigations conducted by Weissenberg (1949, 1965, 1968). In the early part of the 19th century, microsporidean researchers were divided on the origins of the cytoplasmic wall of the xenoma and of the large vesicular nuclei of Glugea. Weissenberg (1922) resolved this problem after dissecting out and studying the early developmental stages of the parasite, and determining that both the cytoplasmic layer and the nuclei belong to the host cell.
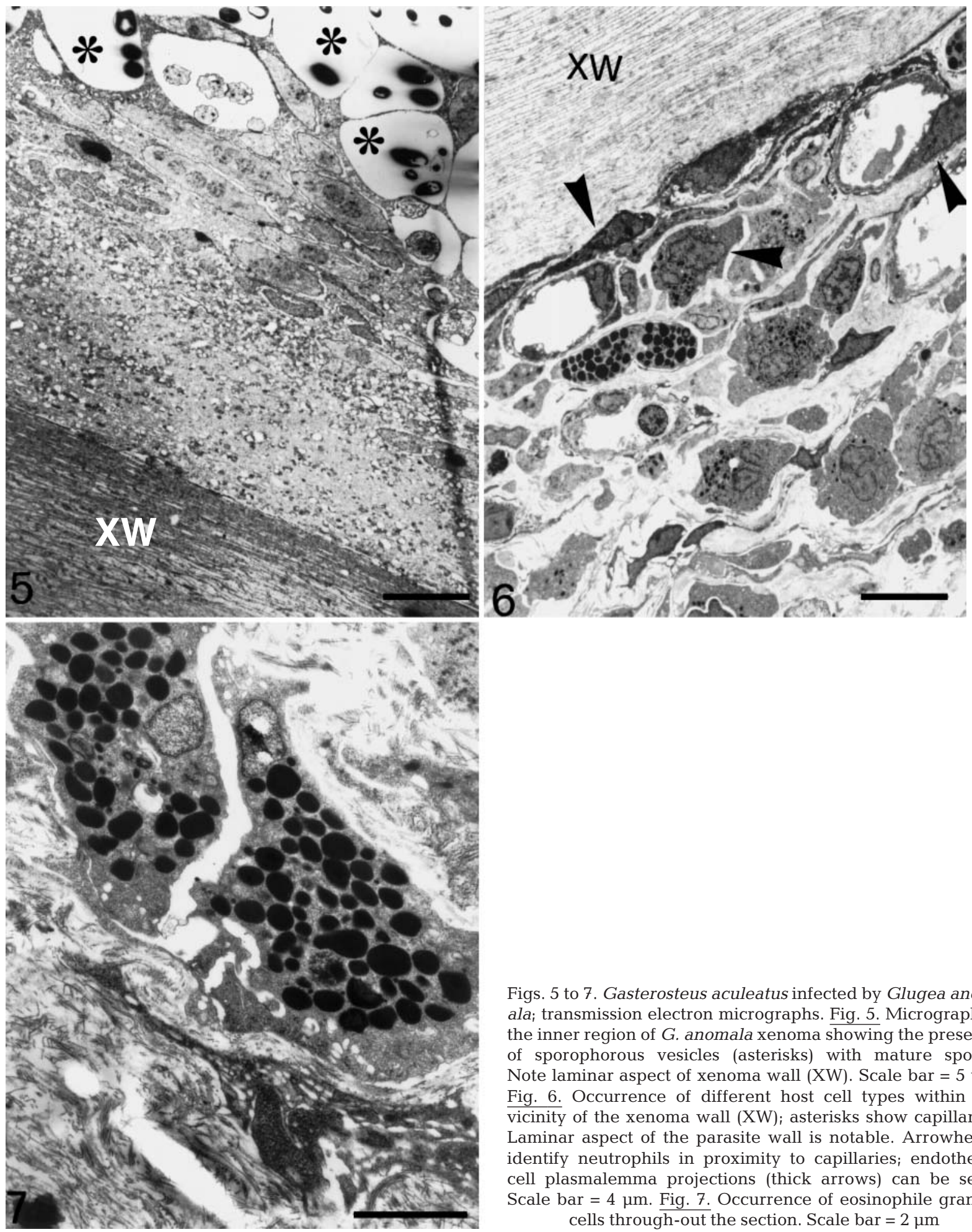

Figs. 5 to 7. Gasterosteus aculeatus infected by Glugea anomaldi transmission electron micrographs. Fig. 5. Micrograph of the inner region of $G$. anomala xenoma showing the presence of sporophorous vesicles (asterisks) with mature spores. Note laminar aspect of xenoma wall (XW). Scale bar $=5 \mu \mathrm{m}$. Fig. 6. Occurrence of different host cell types within the vicinity of the xenoma wall (XW); asterisks show capillaries. Laminar aspect of the parasite wall is notable. Arrowheads identify neutrophils in proximity to capillaries; endothelial cell plasmalemma projections (thick arrows) can be seen. Scale bar $=4 \mu \mathrm{m}$. Fig. 7. Occurrence of eosinophile granule cells through-out the section. Scale bar $=2 \mu \mathrm{m}$ 

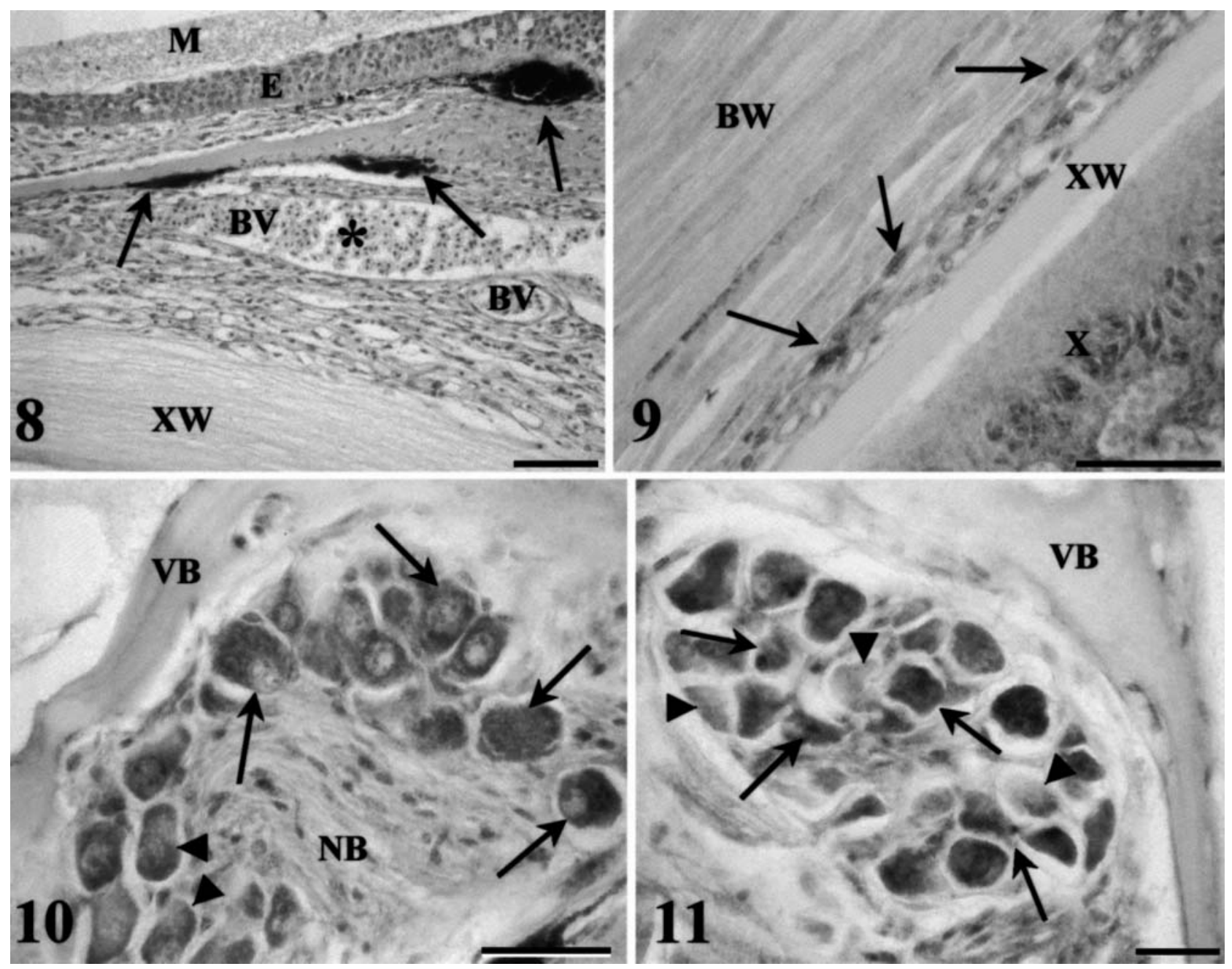

Figs. 8 to 11. Gasterosteus aculeatus infected by Glugea anomala; histological sections. Fig. 8. Section of the body wall of $G$. aculeatus infected with $G$. anomala. Within the dermis, macrophage aggregates are visible (arrows); BV $=$ blood vessel; $\mathrm{M}=$ mucus; $\mathrm{E}=$ epidermis; $\mathrm{XW}=$ xenoma wall. Scale bar $=50 \mu \mathrm{m}$. Fig. 9 . High magnification of the interface between the host body wall (BW) and the cyst of $G$. anomala. Cells immunoreactive to the anti-serotonin serum are indicated by arrows. $\mathrm{X}=\mathrm{xenoma}$. Scale bar $=20 \mu \mathrm{m}$. Fig. 10. Spinal ganglion with neurons immunoreactive to the serotonin antiserum, identified by arrows; neurons that are not immunoreactive to the primary antibody are shown by arrowheads. VB = vertebral bone; $\mathrm{NB}=$ nervous bundle. Scale bar $=20 \mu \mathrm{m}$. Fig. 11. Neurons containing a met-enkephalin-like material within a spinal ganglion, indicated by arrows; nerve bodies that are not immunoreactive to the anti-met-enkephalin serum are identified by arrowheads. Scale bar $=10 \mu \mathrm{m}$

From the observations made in this study, it was found that most xenomas were situated in the peritoneal cavity or positioned subcutaneously within the body wall of the fish; the parasite was occasionally found on the intestine or in the gills. The occurrence of Glugea anomala xenomas has been reported from almost all body organs (Delisle 1972). Several species of Glugea are known from the literature to cause mortality, such as $G$. hertwigi in freshwater smelt Osmerus eperlanus (L.) (Delisle 1972), as well as in O. mordax (Nepszy et al. 1978), and G. anomala in Nothobranchius spp. (Lom et al. 1995). According to Delisle (1972), the mass mortality of adult $O$. eperlanus in the spring results from a combination of physiological exhaustion during the spawning period and Glugea infection.

Concerning MAs, there is no accepted view about the role of such structures in fish; nevertheless, their proliferation has been associated with both physiological and pathological factors such as aging, starvation, infectious disease and intoxication (Vogelbein et al. 1987, Wolke 1992, Couillard \& Hodson 1996, Couillard et al. 1999). In Rivulus marmoratus experimentally parasitized with the coccidian parasite Calyptospora funduli, multifocal granulomatous lesions were noticed in the liver after $30 \mathrm{~d}$ post-infection, 


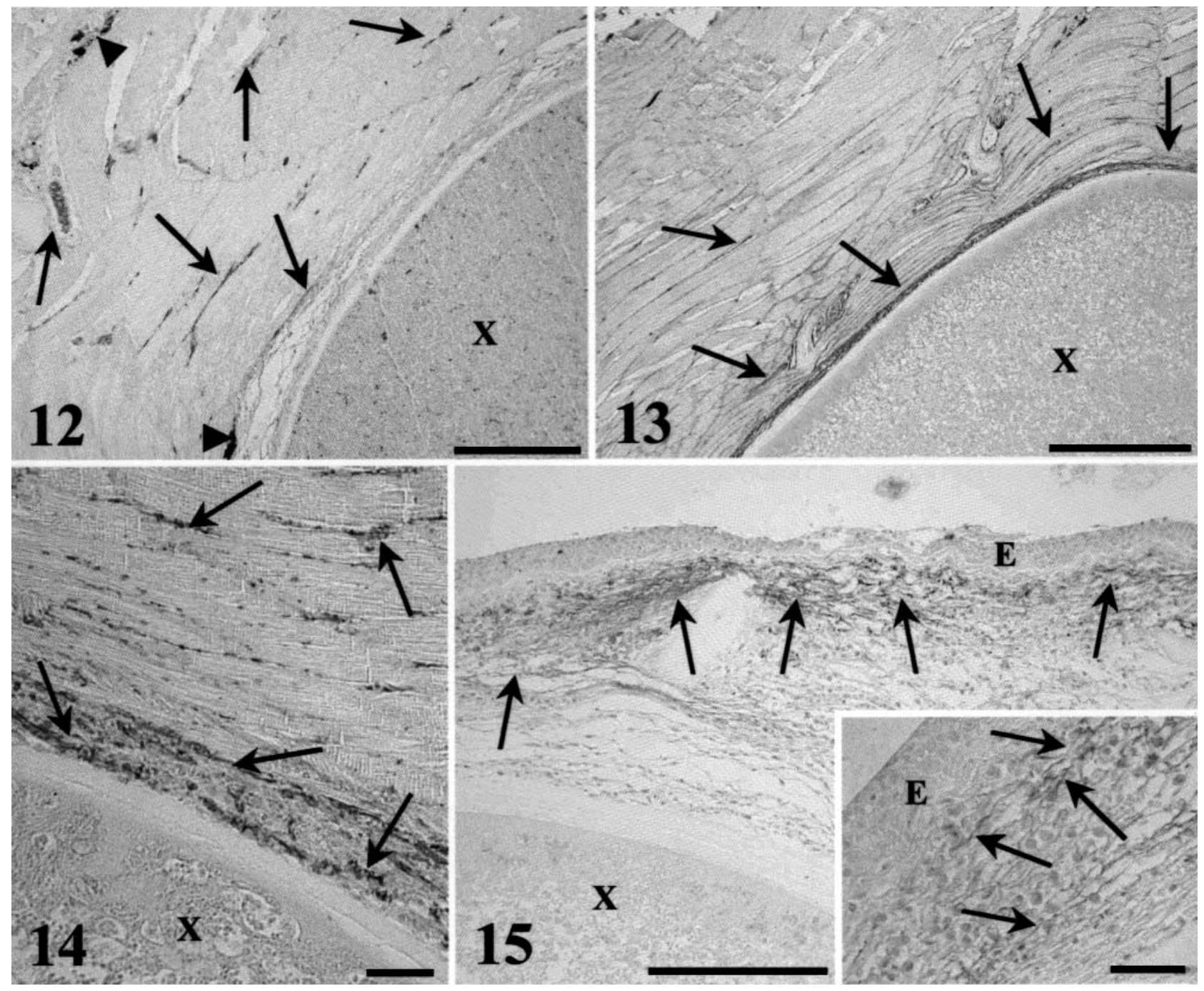

Figs. 12 to 15. Gasterosteus aculeatus infected by Glugea anomala; histological sections. Fig. 12. Nervous fibres immunoreactive to the anti-galanin serum (arrows) in the somatic lateral muscle of the 3-spined stickleback in close proximity to the cyst of $G$. anomala. The arrowheads identify 2 macrophage aggregates within the section. $X=$ xenoma. Scale bar $=100 \mu \mathrm{m}$. Fig. 13 . High number of nervous fibres immunoreactive to leu-enkephalin antiserum (arrows) in the skeletal muscle of the G. aculeatus body wall and in close proximity to a G. anomala xenoma (X). Scale bar $=200 \mu \mathrm{m}$. Fig. 14. High magnification of the host somatic muscle adjacent to the xenoma. Arrows identify nervous fibres that are immunoreactive to the anti-leu-enkephalin serum. Scale bar $=$ $20 \mu \mathrm{m}$. Fig. 15. Within the dermis of the 3-spined stickleback in the immediate vicinity of the G. anomala cyst, a net of thin nervous fibres containing a bombesin-like material can be seen (arrows). The insert shows a high magnification of the interface region, with the arrows identifying nervous fibres within the section. $\mathrm{E}=$ epidermis. Scale bar $=100 \mathrm{~mm}$; insert scale bar $=20 \mu \mathrm{m}$

and after 50 to $150 \mathrm{~d}$ post-infection a progressive increase of melanin and lipofucsin within the resulting MAs was observed (Vogelbein et al. 1987). The results of our survey lends support to the view reported by Vogelbein et al. (1987) that macrophage aggregates are associated with parasite infections and, in all likelihood, represent an inflammatory rather than a granulomatous reaction.

This is the first study in which rodlet cells have been found in close proximity to xenomas of Glugea, although Leino (1996) recorded rodlet cells in the kidneys of Lepomis macrochirus (Rafinesque, 1819) infected with myxosporeans. With reference to their presence in Phoxinus phoxinus (L.), Carassius auratus (L.) and Abramis brama (L.), it has been suggested that they represent inflammatory cells (Dezfuli et al. 2000a, 2003a, Manera et al. 2001). According to Leino (1996), the secretions produced by the rodlet cells have an antibiotic activity. Yet, the precise nature and function of these cells is still a matter of much debate. However, more support, particularly in the last decade, is lent to the notion that these cells are of an endogenous origin 
(Smith et al. 1995, Leino 1996, Iger \& Abraham 1997, Dezfuli et al. 1998, 2000a, 2003a,b, Palenzuela et al. 1999, Koponen \& Myers 2000).

A comparison of the results from the present survey with those gathered from our previous studies in fish infected with helminth parasites (Dezfuli et al. 2000b, 2002, 2003b) noted that there was a similar host reaction in producing a capsule around the helminth, with almost the same structural features as the capsule produced to surround a Glugea anomala xenoma. In our previous investigations, the use of immunohistochemical methods revealed the effect that helminth parasites exert on their host's neuroendocrine system (Dezfuli et al. 2000b, 2002, 2003b). Prior to the current study, it was unknown what effects $G$. anomala had on the host neuroendocrine system.

Fish mast cells, also known as eosinophile granule cells (EGCs), produce a variety of defensive substances such as histamine and serotonin (Reite 1998). In this study, serotonin antiserum was noticed in several EGCs within the connective inflammatory tissue surrounding the Glugea anomala xenoma. A similar finding was observed for the EGCs in Salmo trutta naturally infected with the cestode Cyathocephalus truncatus Pallas, 1781 and the acanthocephalan Pomphorhynchus laevis (Müller, 1776) (Dezfuli et al. $2000 \mathrm{~b}, 2002)$. Furthermore, in rats infected with Trichinella spiralis (Owen, 1835), Railliet 1895 and T. pseudospiralis Garkavi, 1972, a significant increase in serotonin activity was reported in the intestine and muscle (Terenina et al. 1997). This biogenic amine affects vascular permeability and lymphocyte function (Lee et al. 1986). Moreover, serotonin exerts a variety of effects that may influence parasite survival (Fairweather 1997). It could be suggested that G. anomala induces the recruitment of EGCs which secrete serotonin.

The current study revealed the presence of a high number of nervous fibres containing a galanin-like substance in Gasterosteus aculeatus tissue sections infected with Glugea anomala. In contrast, galaninlike positive fibres were not common in the uninfected fish tissue sections. Galanin is a short peptide of 29 amino acids that has been found in the central and peripheral nervous systems of a variety of teleosts and other vertebrate species (Batten et al. 1990, Karila et al. 1993, Holmgren et al. 1994, Philippe et al. 1996, Funakoshi et al. 2000, Kohchi \& Tsutsui 2000). In Atlantic cod Gadus morhua L., Karila et al. (1993) reported that the main physiological action of galanin was to stimulate smooth muscle contraction in the gut wall and gut arteries. Conflicting observations exist on the functions of galanin, and it is postulated that this neuromodulator may not exert the same functions within the different vertebrate classes.
Among the lateral muscle fibres of parasitised Gasterosteus aculeatus, a high number of nervous fibres immunoreactive to anti-leu-enkephalin serum were noticed, the numbers of such fibres being considerably lower in healthy fish. Dezfuli et al. $(2000 b, 2002)$ reported the presence of numerous nervous fibres immunoreactive to met-enkephalin, a strictly related peptide, in the intestine of Salmo trutta infected with Cyathocephalus truncatus or Pomphorhynchus laevis. Enkephalins belong to the endogenous opiate system and play an important role in the modulation of the inflammatory process (Radulovic et al. 1996, Wu et al. 1998). The presence of a high number of fibres positive to a leu-enkephalin-like substance in infected G. aculeatus individuals makes it reasonable to presume that their occurrence in the lateral muscle fibres might be responsible for the same functions that they have in the nervous system of other vertebrates. In other words, by increasing the amount of the leu-enkephalin-like substance secreted, the stickleback tries to modulate the inflammation caused by G. anomala.

A bombesin-like substance was also encountered in a high number of nerve fibres running along the white lateral muscle fibres of infected stickleback tissue, the number in uninfected fish being lower. This neuropeptide was also found within the thin nerve fibres in the inflammatory connective tissue enclosing the xenoma. Previously, Dezfuli et al. (2002) recorded bombesin in the connective capsule that forms around the bulb of Pomphorhynchus laevis. On the basis of our previous observations and of those in the present survey, our hypothesis in relation to the activity of this neuropeptide can now be expanded upon. The presence of this neuromodulator in fish nervous tissue at the site of an inflammation is presumably due to the fact that bombesin could be one of the putative neurotransmitters of the neo-formed network of nervous fibres.

It is possible that the pattern of neuropeptide expression after nerve injury or damage will be different in neurons with different targets (Bergner et al. 2000). This interpretation is consistent with the results of the present survey. Therefore, it is tempting to speculate on whether galanin- and bombesin-like peptides have the same functions in other fish species (see Dezfuli et al. 2000b, 2002, 2003b) as those reported here.

Acknowledgements. The authors would like to thank Mr. L. Brown from the Institute of Aquaculture, University of Stirling, and Dr. Maurizio Manera from the University of Teramo for their valuable technical assistance. This investigation was supported through an award to B.S.D. from the European Union Access to Research Infrastructures (ARI) Action of the Improving Human Potential (IHP) Programme (contract HPRI-CT-1999-00106). 


\section{LITERATURE CITED}

Batten TF, Cambre ML, Moons L, Vandesande F (1990) Comparative distribution of neuropeptide-immunoreactive systems in the brain of the green molly, Poecilia latipinna. J Comp Neurol 302:893-919

Bergner AJ, Murphy SM, Anderson CR (2000) After axotomy, substance $\mathrm{P}$ and vasoactive intestinal peptide expression occurs in pilomotor neurons in the rat superior cervical ganglion. Neuroscience 96:611-618

Couillard CM, Hodson PV (1996) Pigmented macrophage aggregates: a toxic response in fish exposed to bleachedkraft mill effluent? Environ Toxicol Chem 15:1844-1854

Couillard CM, Williams PJ, Courtenay SC, Rawn GP (1999) Histopathological evaluation of Atlantic tomcod (Microgadus tomcod) collected at estuarine sites receiving pulp and paper mill effluent. Aquat Toxicol 44:263-278

Delisle CE (1972) Variations mensuelles de Glugea hertwigi (Sporozoa: Microsporida) chez différents tissus et organes de l'éperlan adulte dulcicole et consequences de cette infection sur une mortalité massive annuelle de ce poisson. Can J Zool 50:1589-1600

Dezfuli BS, Capuano S, Manera M (1998) A description of rodlet cell from the alimentary canal of Anguilla anguilla and their relationship with parasitic helminths. J Fish Biol 53:1084-1095

Dezfuli BS, Simoni E, Rossi R, Manera M (2000a) Rodlet cells and other inflammatory cells of Phoxinus phoxinus infected with Raphidascaris acus (Nematoda). Dis Aquat Org 43:61-69

Dezfuli BS, Arrighi S, Domeneghini C, Bosi G (2000b) Immunohistochemical detection of neuromodulators in the intestine of Salmo trutta Linnaeus naturally infected with Cyathocephalus truncatus Pallas (Cestoda). J Fish Dis 23: 265-273

Dezfuli BS, Pironi F, Giari L, Domeneghini C, Bosi G (2002) Effect of Pomphorhynchus laevis (Acanthocephala) on putative neuromodulators in the intestine of naturally infected Salmo trutta. Dis Aquat Org 51:27-35

Dezfuli BS, Giari L, Konecny R, Jaeger P, Manera M (2003a) Immunohistochemistry, ultrastructure and pathology of gills of Abramis brama from Lake Mondsee, Austria, infected with Ergasilus sieboldi (Copepoda). Dis Aquat Org 53:257-262

Dezfuli BS, Giari L, Arrighi S, Domeneghini C, Bosi G (2003b) Influence of enteric helminths on the distribution of intestinal endocrine cells belonging to the diffuse endocrine system in brown trout, Salmo trutta L. J Fish Dis 26:155-166

Domeneghini C, Radaelli G, Arrighi S, Mascarello F, Veggetti A (2000) Neurotransmitters and putative neuromodulators in the gut of Anguilla anguilla (L.): localizations in the enteric nervous and endocrine systems. Eur J Histochem 44:295-306

Dykovà I, Lom J (1978) Tissue reaction of the three-spined stickleback Gasterosteus aculeatus L. to infection with Glugea anomala (Moniez, 1887). J Fish Dis 1:83-90

Fairweather I (1997) Peptides: an emerging force in host response to parasitism. In: Beckage NE (ed) Parasites and pathogens: effects on host hormones and behaviour. Chapman \& Hall, New York, p 113-139

Funakoshi K, Kadota T, Atobe Y, Nakano M, Hibiya K, Goris RC, Kishida R (2000) Distinct localization and target specificity of galanin-immunoreactive sympathetic preganglionic neurons of a teleost, the filefish Stephanolepis cirrhifer. J Autonom Nervous Syst 79:136-143

Holmgren S, Fritsche R, Karila P, Gibbins I, Axelsson M, Franklin C, Grigg G, Nilsson S (1994) Neuropeptides in the Australian lungfish Neoceratodus forsteri: effects in vivo and presence in autonomic nerves. Am J Physiol 266:R1568-1577

Iger Y, Abraham M (1997) Rodlet cells in the epidermis of fish exposed to stressors. Tissue Cell 29:431-438

Karila P, Jönsson AC, Jensen J, Holmgren S (1993) Galaninlike immunoreactivity in extrinsic and intrinsic nerves to the gut of the Atlantic cod, Gadus morhua, and the effect of galanin on the smooth muscle of the gut. Cell Tissue Res 271:537-544

Karila P, Shahbazi F, Jensen J, Holmgren S (1998) Projections and actions of tachykininergic, cholinergic, and serotonergic neurones in the intestine of the atlantic cod. Cell Tissue Res 291:403-413

Kohchi C, Tsutsui K (2000) Avian galanin: cloning of complementary DNAs and characterization of transcripts in different tissues. J Exp Zool 287:183-190

Koponen K, Myers MS (2000) Seasonal changes in intra- and interorgan occurrence of rodlet cells in freshwater bream. J Fish Biol 56:250-263

Larsson JIR (2000) We recognise Glugea anomala? Scandinavian section, Society of Protozoologists, 22nd annual meeting, Helsingør, Apr 17, 2000. Tom Fenchel, Copenhagen

Lee TDG, Swieter M, Befus AD (1986) Mast cell responses to helminth infection. Parasitol Today 2:186-191

Leino RL (1996) Reaction of rodlet cells to a myxosporean infection in kidney of the bluegill, Lepomis macrochirus. Can J Zool 74:217-225

Lom J, Pekkarinen M (1999) Ultrastrucutural observations on Loma acerinae (Jirovec, 1930) comb. nov. (Phylum Microsporidia). Acta Protozool 38:61-74

Lom J, Noga EJ, Dykovà I (1995) Occurrence of a microsporean with characteristics of Glugea anomala in ornamental fish of the family Cyprinodontidae. Dis Aquat Org 21:239-242

Manera M, Simoni E, Dezfuli BS (2001) The effect of dexametasone on the occurrence and ultrastructure of rodlet cells in goldfish. J Fish Biol 59:1239-1248

Maule AG, Shaw C, Halton DW, Johnston CF, Fairweather I (1989) Localization, quantification, and characterization of pancreatic polypeptide immunoreactivity in the parasitic flatworm Diclidophora merlangi and its fish host (Merlangius merlangius). Gen Comp Endocrinol 74:50-56

Nepszy S, Budd J, Dechtiar AO (1978) Mortality of young-ofthe-year rainbow smelt (Osmerus mordax) in Lake Erie associated with the occurrence of Glugea hertwigi. J Wildl Dis 14:233-239

Palenzuela O, Alvarez-Pellitero P, Sitjà-Bobadilla A (1999) Glomerular disease associated with Polysporoplasma sparis (Myxozoa) infections in cultured gilthead sea bream, Sparus aurata L. (Pisces: Teleostei). Parasitology 118: 245-256

Philippe C, Clerc N, Mazet B, Niel JP (1996) Immunochemical study of galanin in the cat digestive tract and autonomic ganglia. Peptides 17:1331-1335

Pomport-Castillon C, De Jonckheere JF, Romestand B (2000) Ribosomal DNA sequences of Glugea anomala, G. stephani, G. americanus and Spraguea lophii (Microsporidia): phylogenetic reconstruction. Dis Aquat Org 40:125-129

Radulovic J, Mancev Z, Stanojevic S, Vsiljevic T, KovacevicJovanovic V, Pesic G (1996) Modulation of humoral immune response by central administration of leucineenkephalin: effects of mu, delta and kappa opioid receptor antagonists. J Neuroimmunol 65:155-161

Reite OB (1998) Mast cells/eosinophile granule cells of teleostean fish: a review focusing on staining properties and 
functional responses. Fish Shellfish Immunol 8:489-513

Shahbazi F, Karila P, Olsson C, Holmgren S, Conlon JM, Jensen J (1998) Primary structure, distribution and effects on notility of CGRP in the intestine of the cod Gadus morhua. Am J Physiol Reg Int Comp Physiol 44:R19-R28

Smith SA, Cacci T, Marei HE-S, El-Habback HA (1995) Observations on rodlet cells found in the vascular system and extravascular space of angelfish (Pterophillum scalare scalare). J Fish Biol 46:241-254

Sprague V, Vernick SH (1968) Light and electron microscope study of a new species of Glugea (Microsporida, Nosemantidae) in the 4-spined stickleback Apeltes quadracus. J Protozool 15:547-571

Terenina NB, Asatrian AM, Movsessian SO (1997) Neurochemical changes in rats infected with Trichinella spiralis and T. pseudospiralis. Dokl Biol Sci 355:412-413

Vogelbein WK, Fournic JW, Overstreet RM (1987) Sequential development and morphology of experimentally induced melano-macrophage centres in Rivulus marmoratus. J Fish Biol 31:145-153

Editorial responsibility: Wolfgang Körting,

Hannover, Germany
Weissenberg R (1922) Mikrosporidien, Myxosporidien und Chlamydozoen als Zellparasiten von Fischen. Verh Dtsch Zool Ges 27:41-43

Weissenberg R (1949) Cell growth and cell transformation induced by intracellular parasites. Anat Rec 103:101-102

Weissenberg R (1965) Fifty years of research on the lymphocystis virus disease of fishes (1914-1964). Ann NY Acad Sci 126:362-374

Weissenberg R (1968) Intracellular development of the microsporidan Glugea anomala Moniez in hypertrophying migratory cells of the fish Gasterosteus aculeatus L., an example of the formation of 'xenoma' tumors. J Protozool 15:44-57

Wolke RE (1992) Piscine macrophage aggregates: a review. Annu Rev Fish Dis 2:91-108

Wu SX, Li YQ, Shi JW (1998) Temporal changes of preproenkephalin mRNA and leu-enkephalin-like immunoreactivity in the neurons of the caudal spinal trigeminal nucleus and upper cervical cord after noxius stimuli. J Hirnforschung 39:217-222

Submitted: June 10, 2003; Accepted: October 27, 2003 Proofs received from author(s): February 4, 2004 